SB 191

. K3 B5

Copy 1 
NITED STATES DEPARTMENT OF AGRICULTURE

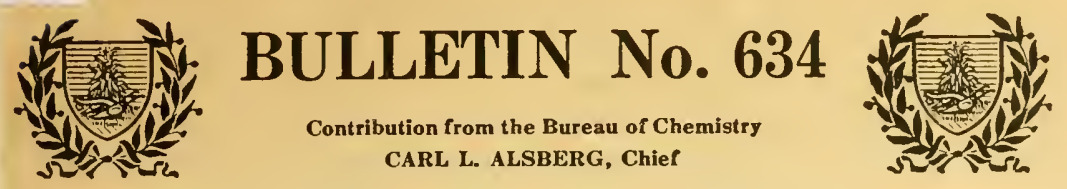

Washington, D. C.

PROFESSIONAL PAPER

April 4, 1918

\section{PHYSICAL AND CHEMICAL STUDY OF THE KAFIR KERNEL.}

By George L. Bidwell,

Chemist in Charge, Cattle Food and Grain Investigation Laboratory.

The grains of nonsaccharine sorghums are becoming very important commercially. Although heretofore largely limited in their use to feeding farm animals, they are now being employed in increasing amounts for human food, a matter which has been studied by the Office of Home Economics of the Department of Agricuiture. ${ }^{1} \quad$ Furthermore, the attention of manufacturers of alcohol and starch is being turned to these grains. As a basis for a process which would utilize nonsaccharine sorghums, probably one of the cheapest sources of starch, in the manufacture of starch and feedstuffs, a study was made in the Bureau of Chemistry of the physical characteristics and chemical composition of the kafir kernel, and the various parts into which it might be separated by milling. Kafir was selected because it is typical of this class of grains, and economically as important as any of them. Therefore a sample of Dawn kafir (Dwarf Blackhull), C. I. 340, was obtained from the Bureau of Plant Industry for this purpose. This sample was grown at the Cereal Field Station, Amarillo, Tex., in 1915, and is the same grain as that used in the food experiments. ${ }^{1}$

The kafir kernel shows some interesting physical characteristics. It is obovoid, or broadly ellipsoid, convex on the outer or dorsal surface, and somewhat flattened on the inner or ventral surface. It might be considered as developed from a sphere by first rolling it in such a way as to lengthen one diameter slightly, then flattening it on one side. The tip is more or less pointed. Beneath the tip is the hilum, or point of attachment of the seed. The outer end usually is rounded, but often bears a tiny, double, claw-like point. The endosperm, the main portion of the kernel, is horny without, inclosing a white, starchy mass. The germ lies in a depression in the endosperm, near the tip of the seed. The kernel is covered with a thin skin or bran coat, dirty white in color, spotted or blotched with dark reddish brown or black. Figure 1 shows the interior structure of the seed. 
Fifty kernels of kafir were measured with a micrometer in three directions. As a kernel of kafir lay on a flat surface the vertical diameter was called the thickness; the shorter horizontal diameter, the width, and the long diameter, the length. The maximum and minimum as well as the average dimensions are shown in the following table:

TABLE I.-Measurements of 50 kernels of diarf black-hulled white kafir, in millimeters.

\begin{tabular}{|c|c|c|c|}
\hline Dimension. & Maximum. & Minimum. & Average. \\
\hline $\begin{array}{l}\text { Thickness } \\
\text { Width.................. } \\
\text { Length.............. }\end{array}$ & $\begin{array}{r}M m . \\
2.74 \\
3.71 \\
4.57\end{array}$ & $\begin{array}{r}M m . \\
2.16 \\
2.95 \\
3.07\end{array}$ & $\begin{array}{r}\Delta I m . \\
2.46 \\
3.33 \\
3.90\end{array}$ \\
\hline
\end{tabular}

One thousand kernels of this sample weighed $23 \frac{1}{2}$ grams. Therefore, one kernel weighs on an average 0.0235 gram. From the
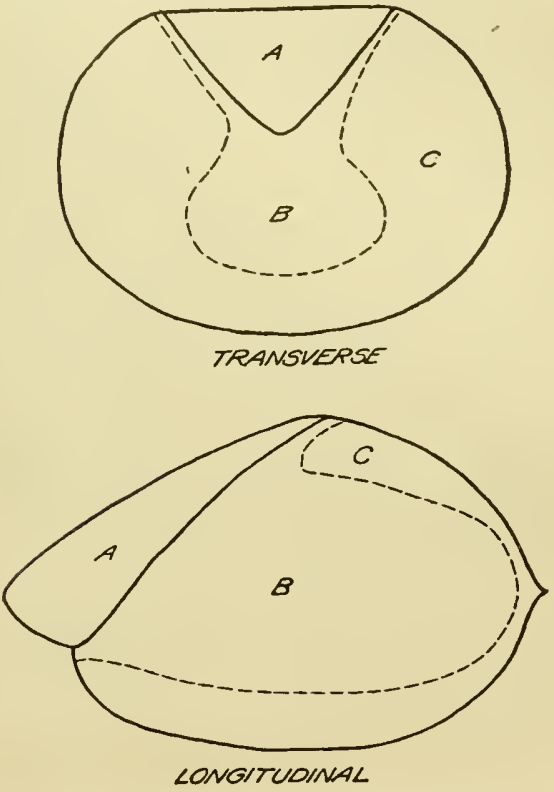

FIG. 1.-Sections of kafir kernels showing $(A)$ germ,

$(B)$ starchy endosperm, $(C)$ horny endosperm. measurements recorded in the table the average volume of these kernels.was calculated and found to be 16.78 cubic millimeters and the surface of such a grain 32.98 square millimeters.

One hundred and fifty-seven grams of kafir were treated with sufficient water to loosen the bran and then separated with a dissecting needle into bran, germ, and endosperm. It was found that only enough water to wet the surface of the kernel was required and with two hours' standing in this condition the bran could be removed easily. Regardless of the time of soaking, there was always some difficulty in getting the bran loose at the tip. The separation of the germ and endosperm at that point was also difficult. For that reason there is probably a small amount of starch mixed with the germ, but special care was taken to keep this as small as possible.

It was found that 6.1 per cent, by weight, of the kafir kernel was bran; 10 per cent was germ; 83.9 per cent was endosperm. This would amount to 1.02 cubic millimeters of bran; 1.68 cubic millimeters of germ; 14.1 cubic millimeters of endosperm, if we assume that those three substances have practically the same specific gravity. On the same assumption the thickness of the bran would average 0.031 millimeter. Surrounding the endosperm lies a very friable, more or less granular layer which seems to carry a large amount of coloring matter. This 
colored layer does not cover the germ but passes between it and the endosperm, as is evidenced in the very highly colored kernels where the germ is seen clearly through the bran by appearing lighter in color than the endosperm. In a small proportion, possibly 1 per cent of the kernels, this coloration was very pronounced. An extended study of this color was not made, but in extracting ground kafir in a paper capsule, both with ether and with chloroform, a red coloration was noted upon the lower part of the capsule, and this coloring matter was also noticeable in the solutions during the crude fiber determination. It was thought that this coloring matter might be associated with tannin, but tests for this substance failed to show its presence. Additional tests by the Pharmacognosy and Leather and Paper Laboratories of this bureau confirmed these results.

The next step in this work was the determination of the composition of the kafir kernel and of the various products into which it had been separated by the method described above. It was found that by grinding the endosperm in a small coffee mill a rough separation of starchy and horny endosperm could be made. The material was reground through the mill several times until it would all pass a 20-mesh sieve; then the material that would pass a 40 -mesh sieve was called "starchy endosperm" (6), and the part that remained on the 40-mesh sieve was called "horny endosperm" (7). No. 6 was floury in appearance and No. 7 had the appearance of sand.

An examination of sections of the seeds shows that the starchy part lies in the center of the endosperm, surrounded on all sides by the horny endosperm, except that it reaches the under side of the germ.

The following samples were analyzed:

(1) Sample of whole kafir.

(2) Sample of whole kafir moistened and allowed to stand over night, dried and ground for analysis in order to approximate but somewhat intensify any changes which might be caused by the moistening of the various parts.

(3) Pure endosperm, as defined above.

(4) Pure germ, as defined above.

(5) Pure bran, as defined above.

(6) Starchy endosperm, as defined above.

(7) Horny endosperm, as defined above.

TABLE II.-The composition of kafir and its various parts on a water-free basis.

\begin{tabular}{|c|c|c|c|c|c|c|c|c|}
\hline Sample. & $\begin{array}{l}\text { Per cent } \\
\text { of whole } \\
\text { kafir. }\end{array}$ & Ash. & $\begin{array}{l}\text { Ether } \\
\text { extract. }\end{array}$ & $\begin{array}{c}\text { Crude } \\
\text { protein } \\
(\mathrm{N} \times 6.25) .\end{array}$ & $\begin{array}{l}\text { Crude } \\
\text { fiber. }\end{array}$ & $\begin{array}{l}\text { Nitrogen- } \\
\text { free ex- } \\
\text { tract. }\end{array}$ & $\begin{array}{l}\text { Pento- } \\
\text { sans. }\end{array}$ & Starch. \\
\hline $\begin{array}{l}\text { (1) Whole kafir....... } \\
\text { (2) Whole kafir mois- } \\
\text { tened and allowed }\end{array}$ & 100.0 & $\begin{array}{r}\text { Per cent. } \\
1.8\end{array}$ & $\begin{array}{r}\text { Pcr cent. } \\
4.1\end{array}$ & $\begin{array}{r}\text { Pcr cent. } \\
12.7\end{array}$ & $\begin{array}{r}\text { Perccnt. } \\
1.8\end{array}$ & $\begin{array}{r}\text { Pcr cent. } \\
79.6\end{array}$ & $\begin{array}{r}P c r \text { cent } \text {. } \\
3.3\end{array}$ & $\begin{array}{r}\text { Pcr cent. } \\
61.9\end{array}$ \\
\hline $\begin{array}{l}\text { to stand over night - } \\
\text { (3) Pure endosperm.. }\end{array}$ & $\begin{array}{r}100.0 \\
83.9\end{array}$ & $\begin{array}{r}1.7 \\
.3\end{array}$ & $\begin{array}{l}4.2 \\
.7\end{array}$ & $\begin{array}{l}12.7 \\
12.7\end{array}$ & $\begin{array}{r}1.8 \\
.8\end{array}$ & $\begin{array}{l}79.6 \\
85.5\end{array}$ & $\begin{array}{l}3.8 \\
1.9\end{array}$ & $\begin{array}{l}63.2 \\
69.3\end{array}$ \\
\hline (4) Pure germ....... & 10.0 & 13.2 & 31.5 & 19.3 & 3. & & 6.1 & ............ \\
\hline $\begin{array}{l}\text { (5) Pure bran ......... } \\
\text { (6) Starchy endo- }\end{array}$ & - & $?$ & 6 & 4.8 & 16. & 70 & 18. & 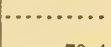 \\
\hline $\begin{array}{l}\text { sperm } \\
\text { (7) Horny endosperm }\end{array}$ & $\begin{array}{l}35.0 \\
48.9\end{array}$ & $\begin{array}{l}.3 \\
.3\end{array}$ & .8 & $\begin{array}{l}10.1 \\
13.7\end{array}$ & .8 & $\begin{array}{l}86.5 \\
83.8\end{array}$ & $\begin{array}{l}1.9 \\
1.6\end{array}$ & $\begin{array}{l}70.4 \\
68.8\end{array}$ \\
\hline
\end{tabular}


An attempt to determine galactans on these samples was made, but the results are omitted, since in no case were the results over 1 per cent and on attempting to recover the mucic acid from the precipitates none was found.

The methods of analysis were those of the Association of Official Agricultural Chemists, as given in the journal of that association. The starch was estimated by the diastase method.

The results on sample No. 2 show that no change which could be detected by the analyses made was caused by soaking.

These analyses may well be compared with those of different parts of the corn kernel made by Hopkins, Smith, and East ${ }^{1}$ in their study of the structure of the corn kernel. In this work three samples of corn differentiated by the amount of protein contained, namely, low, medium, and high, were examined. The one containing the medium amount of protein has been selected for comparison with kafir, since it is nearest the normal. They divided the horny endosperm into two parts, "horny gluten" and "horny starch." These analyses have been combined so as to compare with kafir "horny endosperm." They also divided the starchy portion into "crown starch" and "tip starch." These have also been combined to correspond to kafir "starchy endosperm."

The following table compares the parts of the kafir kernel with the corresponding parts of the corn kernel:

TABLE III.-Comparison of kafir and corn separations.

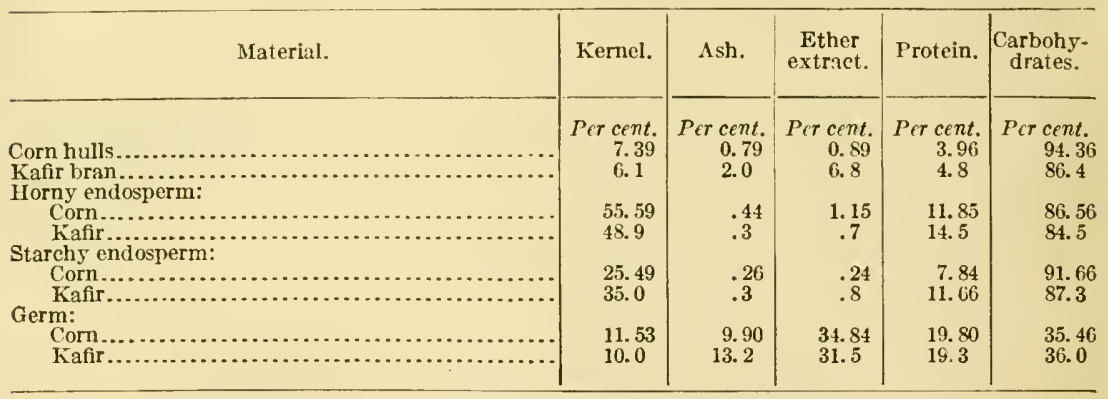

The figures for percentage of the various parts of the corn kernel are taken from Table III on page 87 of the Illinois bulletin, and those for the composition are taken from Table I, on page 83 .

In comparing the analyses of kafir bran with corn bran, or corn hulls, the most noticeable difference is in ether extract. The kernel of corn is developed under the protection of husks, but the kernel of kafir grows in a somewhat exposed condition. When measuring the kernels it was found that they scemed slippery and it was difficult to hold them with a forceps. This led to the belief that the kernel 
might be covered with a protective film of some waxy or fatty material and it seemed worth while to ascertain the nature of it. A large quantity of whole kafir therefore was washed rapidly with ether and chloroform. This removed soluble material to the extent of one-tenth of 1 per cent. On examination this was found to contain 16 per cent of unsaponifiable matter, which indicates that the kernel is probably covered with a film of waxy material.

According to Baird ${ }^{1}$ the amount of unsaponifiable matter in kafir fat is 1.7 per cent. The kafir fat studied by him, however, was a gasoline extract of the entire grain, and he described it as having a consistency like vaseline although somewhat harder. In this investigation the ether extract from the pure bran was found to be somewhat harder than that described by Baird, and it was found that it hardened rapidly in the fat flasks and cracked from shrinking. The ether extract from the germ, on the other hand, was found to be a clear yellowish oil. The kafir fat described by Baird was a mixture of the solid extract from the bran and the liquid extract from the germ, as well as a small amount from the endosperm, and thus the material had the consistency he describes.

In studying the analysis of the two portions of the endosperm of kafir and corn it will be noted that, though the protein is higher in the kafir, the horny endosperm in each case has more protein than has the starchy endosperm. The germs of corn and kafir are very similar in composition.

Table IV gives the distribution of the various constituents among the different parts of the kernel expressed in percentages of the total amount of each constituent in the entire grain:

TABLE IV.-Distribution of constituents.

\begin{tabular}{|c|c|c|c|c|c|c|}
\hline Material. & $\begin{array}{l}\text { Whole } \\
\text { kafir. }\end{array}$ & Ash. & $\begin{array}{c}\text { Ether } \\
\text { extraet. }\end{array}$ & $\begin{array}{c}\text { Crude } \\
\text { protein } \\
(\mathrm{N} \times 6.25) .\end{array}$ & $\begin{array}{l}\text { Crude } \\
\text { fiber. }\end{array}$ & $\begin{array}{l}\text { Nitrogen- } \\
\text { free ex- } \\
\text { tract. }\end{array}$ \\
\hline $\begin{array}{l}\text { Germ } \\
\text { Bran } \\
\text { Starehy endosperm } \\
\text { Horny endosperm } \\
\text { Whole endosperm }\end{array}$ & $\begin{array}{r}\text { Per cent. } \\
10.0 \\
6.1 \\
35.0 \\
48.9 \\
83.9\end{array}$ & $\begin{array}{r}\text { Percent. } \\
77.9 \\
7.2 \\
6.2 \\
8.7 \\
14.9\end{array}$ & \begin{tabular}{|r} 
Per cent. \\
75.2 \\
9.9 \\
6.7 \\
8.2 \\
14.9
\end{tabular} & $\mid \begin{array}{r}\text { Per cent. } \\
15.5 \\
2.3 \\
28.4 \\
53.8 \\
82.2\end{array}$ & $\begin{array}{r}\text { Per cent. } \\
19.1 \\
49.7 \\
14.1 \\
17.1 \\
31.2\end{array}$ & $\begin{array}{r}\text { Per cent. } \\
4.1 \\
5.5 \\
38.4 \\
52.0 \\
90.4\end{array}$ \\
\hline
\end{tabular}

The results of this study show that corresponding parts of the kafir and corn kernels resemble each other in composition and appearance, and lead us to believe that if kafir were handled in a manner similar to that used in the preparation of corn products, kafir products might be substituted for the corresponding corn products. 


\section{PUBLICATIONS OF THE U. S. DEPARTMENT OF AGRICULTURE RELATING TO THE SUBJECT OF THIS BULLETIN.}

\section{PUBLICATIONS AVAILABLE FOR FREE DISTRIBUTION BY THE DEPARTMEN'T.}

Breeding Millet and Sorgo for Drought Adaptation. (Department Bulletin No. 291.)

Studies on the Digestibility of the Grain Sorghums. (Department Bulletin No. 470.) Experiments in Determination of Digestibility of Millets. (Department Bulletin No. 525.)

Kafir as a Grain Crop. (Farmers' Bulletin No. 552.)

Use of Corn, Kafir, and Cowpeas in the Home. (Farmers' Bulletin No. 559.)

Uses of Sorghum Grain. (Farmers' Bulletin No. 686.)

FOR SALE BY THE SUPERINTENDEN'T OF DOCUMENTS, GOVERNMENT PRINTING OFFICE, WASHINGTON, D. C.

Corn, Milo, and Kafir in Southern Great Plains Area. (Department Bulletin 242.) Price, 5 cents.

Saccharine Sorghums for Forage. (Farmers' Bulletin No. 246.) Price, 5 cents.

Better Grain-Sorghum Crops. (Farmers' Bulletin No. 448.) Price, 5 cents.

Importance and Improvement of Grain Sorghums. (Bureau of Plant Industry Bulletin No. 203.) Price, 10 cents.

Grain-Sorghum Production in San Antonio Region of Texas. (Bureau of Plant Industry Bulletin 237.) Price, 5 cents.

Kaoliangs, New Group of Grain Sorghums. (Bureau of Plant Industry Bulletin No. 253.) Price, 15 cents.

ADDITIONAL COPIES

OF THIS PUBLICATION MAY BE PROCURED FROM THE SUPERINTENDENT OF DOCUMENTS

GOVERNMENT PRINTING OFFICE WASHINGTON, D. C. A T

5 CENTS PER COPY 



\section{LIBRARY OF CONGRESS}

INU

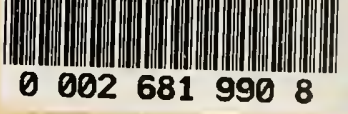


